\title{
Finansal Varlıkların Ölçme ve Muhasebeleștirme Esaslarının Büyük ve Orta Boy İşletmeler İçin Finansal Raporlama Standardı ve Türkiye Finansal Raporlama Standartları Açısından Karşılaştırılması
}

\section{Comparison Of The Measurement And Accounting Principles Of Financial Assets In Terms Of The Financial Reporting Standard For Large And Medium-Sized Enterprises And Turkish Financial Reporting Standards}

\author{
Erkan ÖZTÜRK \\ Kirklareli Üniversitesi \\ İktisadi ve İdari Bilimler Fakültesi \\ İșletme Bölümü \\ Kırklareli, Türkiye \\ orcid.org/0000-0002-9356-1557 \\ erkan.ozturk@klu.edu.tr \\ Özet
}

Kamu Gözetimi Muhasebe ve Denetim Standartları Kurumu (KGK) tarafından hazırlanan Büyük ve Orta Boy İşletmeler İçin Finansal Raporlama Standardı (BOBİ FRS) hakkında tebliğ 29/07/2017 tarihli Resmi Gazete'de yayımlanarak yürürlüğe girmiştir. Buna göre; bağımsız denetime tabi olup Türkiye Finansal Raporlama Standartları'nı (TFRS) uygulamayan şirketler, 01/01/2018 tarihi ve sonrasında başlayan hesap dönemlerinde finansal tablolarını BOBI FRS'ye göre hazırlamaları gerekmektedir. $\mathrm{Bu}$ çalışmada, TFRS seti içerisinde önemli bir yeri olan finansal varlıkların TFRS ve BOBİ FRS açısından karşılaştırması yapılmıştır. Çalışmanın sonunda, tespit edilen farklılıkları açıklamak amacıyla çeşitli örnekler sunulmuştur.

Anahtar Kelimeler: Büyük ve Orta Boy İşletmeler İçin Finansal Raporlama Standard, Türkiye Finansal Raporlama Standartları, Finansal Varlıklar.

\section{Abstract}

The notification on Financial Reporting Standard for Large and Medium-Sized Enterprises that was prepared by Public Oversight, Accounting and Auditing Standards Authority was published on 29/07/2017 and entered. According to this; enterprises that subject to independent audit and don't apply Turkish Financial Reporting Standards (TFRS) must prepare their financial statements according to this new set during fiscal periods starting on after 01/01/2018. In this study, comparison of financial assets that have an important place in TFRS set have been made in terms of TFRS and Financial Reporting Standard for Large and Medium-Sized Companies. At the end of the study, several examples have been presented to explain the detected differences.

Keywords: The Financial Reporting Standard For Large and Medium Sized Companies, Turkish Financial Reporting Standards, Financial Assets. 


\section{GİRİŞ}

İşletmelerin gerçeğe uygun finansal raporlar elde edebilmeleri amacına yönelik olarak uzun yıllardır süre gelen çalışmalar, bugün birçok ülkenin muhasebe sistemi üzerinde önemli katkılar sağlamıştır. Bu konuda Türkiye'de sarf edilen çalışmalar Sermaye Piyasası Kurulu (SPK) öncülüğünde başlamış olup; uluslararası nitelikteki finansal bilgi ihtiyacının karşılanabilmesi amacıyla 2005 yılından itibaren SPK mevzuatına tabi olan ve borsada işlem gören şirketler, finansal raporlarını uluslararası muhasebe standartları ile uyumlu olarak yayımlamaya başlamışlardır.

Günümüz Türkiye'sindeki muhasebe düzenlemeleri Maliye Bakanlığı ve Kamu Gözetimi, Muhasebe ve Denetim Standartları Kurumu (KGK) direktifleri çerçevesinde şekillenmektedir. Maliye Bakanlığı'nca 26.12.1992 tarihinde yayımlanarak 01.01.1994 tarihinden itibaren uygulanmaya başlanan Muhasebe Sistem Uygulama Genel Tebliği (MSUGT), Türkiye'deki muhasebe düzenlemeleri açısından temel teşkil etmektedir. Bununla birlikte, KGK tarafindan yayımlanan Türkiye Finansal Raporlama Standartları (TFRS) seti, Kamu Yararını İlgilendiren Kuruluş (KAYİK) tanımı kapsamında yer alan şirketler tarafindan uygulanmaktadır.

KGK tarafından hazırlanan ve bağımsız denetime tabi olmakla birlikte KAYİK kapsamında olmayan şirketler tarafından uygulanacak olan diğer bir set olan Büyük ve Orta Boy İşletmeler İçin Finansal Raporlama Standardı (BOBİ FRS) seti, 29/07/2017 tarihli Resmi Gazete'de yayımlanarak yürürlüğe girmiştir. BOBİ FRS seti, bağımsız denetime tabi olup TFRS uygulama zorunluluğu bulunmayan işletmeler tarafindan 01/01/2018 tarihinden itibaren uygulanmaya başlanacaktır.

Yapılan bu çalışmada, öncelikli olarak BOBİ FRS'yi uygulamak zorunda olan şirketlerin ölçme ve muhasebeleştirme esaslarında ne gibi değişikliklerle karşı karşıya olduklarına ilişkin genel bir değerlendirme yapılmıştır. Ardından, finansal varlıklarla ilgili olarak BOBI FRS setinde sunulan muhasebe uygulamaları ile TFRS setinde sunulan muhasebe uygulamaları karşılaştırılarak, tespit edilen farklılıkların finansal raporlar üzerinde ne gibi etkilerinin olacağı değerlendirilmiştir.

\section{BOBİ FRS'YE YÖNELİK GENEL BAKIŞ}

Farklı ülkelerdeki sermayenin uluslararası hareket kabiliyeti kazanması ve dolayısıyla dünya borsalarının birbirleri ile rekabet eder hale gelmesi, küresel muhasebe uygulamalarını zorunlu bir yakınsama süreci içerisine sokmuştur (Burton, 2012: 35, 36). Uluslararası düzeyde karşılaştırılabilir finnansal raporlama yapılabilmesi amacıyla Türkiye'de de uzun yıllardır süregelen çalışmalar bulunmaktadır. Bu çalışmaların bugün geldiği aşamada, tam set TFRS uygulaması KAYİK kapsamında yer alan şirketler için zorunlu hale gelmiştir. Bununla birlikte; tam set TFRS'yi uygulamak zorunda olmayan diğer tüm işletmeler halen 1994 yılından bu yana yürürlükte olan MSUGT'e göre finansal raporlama yapmaktadır. Ancak, esas itibariyle 213 Sayılı Vergi Usul Kanunu'nun (VUK) mükerrer 175. ve 257. maddelerine dayanılarak oluşturulan MSUGT, işletmelerin finansal durumunu gerçeğe uygun bir biçimde sunmaktan ziyade vergi matrahını doğru tespit edebilmek amacına hizmet etmektedir (Yünlü, 2016: 27). Ayrıca, MSUGT'un bilanço tarihi sonrası olaylar, ertelenmiş vergi, konsolidasyon vb. bazı konularda içerik sunmuyor olması, MSUGT'e göre oluşturulan finansal raporların uluslararası düzeydeki karşılaştırılabilirliğini önemli ölçüde ortadan kaldırmaktadır.

01/01/2018 tarihi itibariyle uygulanmaya başlanacak olan BOBİ FRS seti, tam set TFRS'leri uygulamak zorunda olmamakla birlikte bağımsız denetime tabi olan şirketler 
tarafından uygulanacaktır. BOBİ FRS seti, uluslararası ölçekte kabul gören karşılaştırılabilir finansal raporlar elde edilebilecekleri yeni bir muhasebe düzeni getirebilmek amacına yönelik olarak 6102 Sayılı Türk Ticaret Kanunu'nun (TTK) 88. Maddesi'nin verdiği yetki doğrultusunda KGK tarafından hazırlanmıştır. Böylelikle, uluslararası standartlar ölçeğinde finansal raporlamanın uygulama alanını genişleten yeni bir çerçeve ortaya çıkmıştır. BOBİ FRS setinin hazırlanmasındaki diğer bir önemli sebep ise, bağımsız denetime uygun ölçüde kabul edilebilir finansal raporlar elde edilebilmesidir. Diğer bir ifadeyle, BOBİ FRS seti ile hem uluslararası alanda, hem de bağımsız denetim alanında kabul edilebilir bir ölçek sunulması hedeflenmektedir. Dolayısıyla; BOBİ FRS setinin kabul edilebilirliği, hem Uluslararası Finansal Raporlama Standartları'na (UFRS) yakınsak finansal raporlar elde edilebilmesi açısından, hem de bağımsız denetimin kabulü ve devamı için gereken en önemli şartlardan birinin sağlanabilmiş olması açısından büyük önem arz etmektedir.

\subsection{BOBİ FRS Uygulamak Zorunda Olan Şirketlerin Kapsamı}

KGK'nın kuruluşunu da resmi olarak açıklayan ve 2 Kasım 2011 tarihli ve 28103 sayılı Resmi Gazete'de yayımlanan 660 Sayılı Kanun Hükmünde Kararname'nin (KHK) 2. Maddesi'nde KAYİK kapsamına alınan şirketler "halka açık şirketler, bankalar, sigorta, reasürans ve emeklilik şirketleri, faktöring şirketleri, finansman şirketleri, finansal kiralama şirketleri, varlık yönetim şirketleri, emeklilik fonları, ihraççılar ve sermaye piyasası kurumları ile faaliyet alanları, işlem hacimleri, istihdam ettikleri çalışan sayısı ve benzeri ölçütlere göre önemli ölçüde kamuoyunu ilgilendirdiği için Kurum tarafından bu kapsamda değerlendirilen kuruluşlar" olarak tanımlanmıştır. Her ne kadar yalnızca KAYİK kapsamında değerlendirilen şirketler tam set TFRS'leri uygulamak zorunda olsa da, bağımsız denetime tabi olan şirketlerin sayısında yıldan yıla meydana gelen artışlar, TFRS'lerin uygulama alanının genişletilmesi ihtiyacını doğurmuştur.

Tam set TFRS'lerin uygulama alanının genişletilmesi, beraberinde birtakım adaptasyon problemlerini de ortaya çıkarmaktadır. BOBI FRS seti, tam set TFRS'lere geçişte karşılaşılan problemler göz önünde bulundurularak, MSUGT ve TFRS'nin harmonize edilmiş bir formunu sunmaktadır. Diğer bir ifadeyle; BOBİ FRS seti, bağımsız denetime tabi olmakla birlikte KAYİK kapsamında olmayan, yani TFRS'leri uygulamayan şirketlerin finansal raporlarını uluslararası ölçeklere daha yakın bir biçimde hazırlayabilmeleri için kolaylaştırılmış bir set olarak karşımıza çıkmaktadır.

Tablo 1. BKK İle Bağımsız Denetim Kapsamına Alınan Şirketler

\begin{tabular}{|c|c|c|c|c|}
\hline & 2013 & 2014 & 2015 & 2016 \\
\hline Aktif Toplamı & $\begin{array}{l}150 \text { milyon } \\
\text { TL ve üzeri }\end{array}$ & $\begin{array}{l}75 \text { milyon } \\
\text { TL ve üzeri }\end{array}$ & $\begin{array}{l}50 \text { milyon } \\
\text { TL ve üzeri }\end{array}$ & $\begin{array}{l}40 \text { milyon } \\
\text { TL ve üzeri }\end{array}$ \\
\hline $\begin{array}{l}\text { Yıllık Net Satış } \\
\text { Hasılatı }\end{array}$ & $\begin{array}{l}200 \text { milyon } \\
\text { TL ve üzeri }\end{array}$ & $\begin{array}{l}150 \text { milyon } \\
\text { TL ve üzeri }\end{array}$ & $\begin{array}{l}100 \text { milyon } \\
\text { TL ve üzeri }\end{array}$ & $\begin{array}{l}80 \text { milyon } \\
\text { TL ve üzeri }\end{array}$ \\
\hline Çalışan Sayısı & $\begin{array}{l}500 \text { çalışan } \\
\text { ve üzeri }\end{array}$ & $\begin{array}{l}250 \text { çalışan } \\
\text { ve üzeri }\end{array}$ & $\begin{array}{l}200 \text { çalışan } \\
\text { ve üzeri }\end{array}$ & $\begin{array}{l}200 \text { çalışan } \\
\text { ve üzeri }\end{array}$ \\
\hline
\end{tabular}

Kaynak: (Özerhan, 2016: 309). 
Tablo 1'de, bağımsız denetime tabi olan şirketler için Bakanlar Kurulu Kararıyla (BKK) belirlenen kriterler yıllar itibariyle sunulmuştur.

Bakanlar Kurulu Kararıyla belirlenen ve Tablo 1'de sunulmuş olan kriterlerden en az ikisini art arda iki hesap döneminde aşan şirketler, izleyen yılda bağımsız denetime tabi olmaktadır. Söz konusu kriterler incelendiğinde, yıllar itibariyle rakamların azaltılması sebebiyle bağımsız denetim kapsamına alınan şirket sayısının giderek arttırıldığ1 görülmektedir. Ancak; 29/07/2017 tarihli Resmi Gazete'de yayımlanan BOBİ FRS Tebliği'nin 6. Maddesi'ndeki büyük işletme kapsamının 2014 yılındaki kriterler baz alınarak değerlendirildiği görülmektedir. Buna göre, BOBİ FRS seti ilk etapta Tablo 1'de yer alan 2014 yılına ait kriterlerden en az ikisini art arda iki raporlama döneminde aşan şirketler tarafindan uygulanacaktır.

\subsection{Finansal Varlıklar İle İlgili Olarak BOBİ FRS'nin Öne Çıkan Özellikleri}

BOBİ FRS seti hem MSUGT'un, hem de TFRS'lerin bazı özelliklerini içerisinde barındırmaktadır. Diğer bir ifadeyle, BOBİ FRS ile birlikte mevcut muhasebe düzeni TFRS ilke ve uygulamalarına biraz daha yakınsamıştır. Ancak yine de TFRS seti ile tam uyum söz konusu değildir.

Finansal varlıkların ölçümü ile ilgili olarak BOBİ FRS setinin TFRS'ye yakınsayan özelliklerinden bazıları aşağıdaki gibi özetlenebilmektedir:

- TFRS'lere göre finansal araç oluşturan hasılat ve alımlara ilişkin ödemeler vade süresine bakılmaksızın peşin değer üzerinden ölçülmekte ve vade farkları ayrıştırılmaktadır. Hasılatın vade farkları faiz geliri olarak, alımlara ilişkin ödemelerin vade farkları ise finansman gideri olarak muhasebeleştirilmektedir. BOBİ FRS'de ise vade farklarının ayrıştırılması, vadeye ilişkin sürenin bir yılı aşması durumunda yapılmaktadır. Diğer bir ifadeyle, vadenin bir yılı aşması durumunda TFRS hükümleri uygulanıyorken; vadenin bir yılı aşmaması durumunda mevcut muhasebe düzeni uygulamalarına devam edilmektedir.

- BOBİ FRS seti değerleme ölçüleri açısından da TFRS'lere yakınsayan uygulamalar sunmaktadır. Finansal araçların dönem sonu değerlemesinde itfa edilmiş maliyet ölçüsünün kullanılması örnek olarak gösterilebilir.

- BOBİ FRS'nin TFRS'lere yakınsayan bir diğer özelliği ise etkin faiz yönteminin kullanılmasıdır. TFRS'lerde ticari ve diğer alacaklar ile ticari ve diğer borçların ilk muhasebeleştirmesi işlem fiyatı üzerinden ölçülmekte, sonraki ölçümlerde itfa edilmiş maliyeti üzerinden ölçülmekte ve etkin faiz yöntemine göre hesaplanan farklar kar ya da zararda muhasebeleştirilmektedir. BOBİ FRS'de ilk kayda alındığ 1 tarih itibariyle tahsil edileceği veya ödeneceği tarih arasındaki süre bir yıl veya kısa olan alacak ve borçlar itibari değer üzerinden, bir yıl veya daha uzun olan alacak ve borçlar ise itfa edilmiş değerleri üzerinden ölçülmektedir. Etkin faiz yöntemine göre hesaplanan faiz kar ya da zararda raporlanmaktadır.

- BOBİ FRS'nin TFRS'lere yakınsayan bir diğer özelliği ise borçlanma araçları ve borsada ve/veya teşkilatlanmış diğer piyasalarda işlem özkaynak araçlarındaki yatırımların ilk muhasebeleştirilmesinde işlem fiyatının kullanılmasıdır. MSUGT'ne göre yapılan muhasebeleştirmelerde işlem fiyatı ölçüsünün yer almamasına karşın; BOBİ FRS'de görülen bu uygulama ile muhasebeleştirme ölçülerinin TFRS hükümlerine yakınsadığı görülmektedir. 
3. FINANSAL VARLIKLARDA SINIFLANDIRILMA, ÖLÇÜM VE MUHASEBELEŞTIRILILME ESASLARININ TFRS VE BOBİ FRS AÇISINDAN İNCELENMESI

\subsection{Finansal Varlıkların TFRS ve BOBİ FRS Açısından Sınıflandırılması}

TMS 32 FINANSAL ARAÇLAR: SUNUM standardında finansal araç, "Bir işletmenin finansal varlığı ile diğer bir işletmenin finansal borcunda ya da özkaynağa dayalı finansal aracında artışa neden olan herhangi bir sözleşmedir." şeklinde tanımlanmıştır (TMS 32, Md. 11). Bu tanıma göre finansal araçlar; finansal varlıklar ve finansal borçlardan oluşmaktadır. BOBİ FRS'de de finansal araç sınıflaması için TMS 32 hükümleri referans alınmıştır. Buna göre finansal araçlar finansal varlık, finansal yükümlülük ve özkaynak aracı olarak sınıflandırılmaktadır (BOBİ FRS, Md. 9.4).

Finansal araçların sınıflandırılması, ilk muhasebeleştirilmesi ve sonraki ölçümlerine ilişkin finansal raporlama ilkelerinin yer aldığı TFRS 9 FINNANSAL ARAÇLAR standardına göre finansal varlıklar; itfa edilmiş maliyeti ile ölçülen finansal varlıklar, gerçeğe uygun değer farkı kar ya da zarara yansıtılarak ölçülen finansal varlıklar ve gerçeğe uygun değer farkı diğer kapsamlı gelire yansıtılarak ölçülen finansal varlıklar olarak sinıflandırılmaktadır (TFRS 9, Md. 4.1).

Finansal varlıklara ilişkin BOBİ FRS'de yer alan tanımlamalar ise aşağıdaki gibidir:

- Ticari ve Diğer Alacaklar: İşletmenin ticari ve ticari olmayan işlemlerinden kaynaklanan senetli ve senetsiz alacaklarından oluşmaktadır (BOBİ FRS, Md. 9.7).

- Borçlanma Araçları: Finansal varlık olarak sınıflandırılan vadeli mevduatlar, devlet tahvilleri, hazine bonosu veya özel sektör tahvil ve bonoları borçlanma araçlarına örnek olarak sunulmaktadır (BOBİ FRS, Md. 9.13).

- Özkaynak Araçlarındaki Yatırımlar: BOBİ FRS'de özkaynak araçlarındaki yatırımlar olarak adlandırılan finansal varlıklara ilişkin açık bir tanıma yer verilmemiştir. Bununla birlikte; TMS 32 FINANSAL ARAÇLAR: ÖLÇÜM standardında özkaynağa dayalı finansal aracın tanımı "İşletmenin tüm borçları çıkarıldıktan sonra varlıklarında bir payı/hakkı gösteren sözleşmedir." şeklinde tanımlanmaktadır (TMS 32, Md. 11).

- Diğer Finansal Varlıklar: Varlığa dayalı menkul kıymetler, türev finansal araçlar ve kredi verilmesine ve kredi alınmasına ilişkin taahhütler gibi, BOBİ FRS setinde tanımlanmış olan diğer finansal araçlar bu sınıflamaya tabidir (BOBİ FRS, Md. 9.22).

TMS 28 İŞTİRAKLERDEKİ VE İŞ ORTAKLIKLARINDAKİ YATIRIMLAR ve TFRS 10 KONSOLIDE FINANSAL TABLOLAR standartları ile ölçülen iştirakler ve bağlı ortaklıklar, BOBİ FRS'de finansal varlık olarak sınıflandırılmamaktadır.

\subsection{Finansal Varlıkların TFRS 9 FINANSAL ARAÇLAR Standardı ve BOBİ FRS Standardı Açısından Ölçümü ve Muhasebeleştirilmesi}

\subsection{1. İlk Muhasebeleştirmeye İlişkin Açıklamalar}

Finansal varlıkların TFRS ve BOBİ FRS açısından ilk muhasebeleştirmeye ilişkin ilke ve esaslar aşağıda gibi özetlenmeye çalışılmıştır: 


\section{- Ticari ve Diğer Alacaklar:}

Ticari ve diğer alacaklar finansal varlık olarak sınıflandırıldıklarından TFRS 9'un kapsamı içerisinde tanımlanmaktadır. Bununla birlikte, önemli bir finansal bileşen sahip olmayan ticari alacakların ilk muhasebeleştirmesinde, TFRS 15 hükümleri uygulanarak işlem fiyatı esas alınmakta (TFRS 9, Md. 5.1; TFRS 15, Md. 47), izleyen dönemlerde ise TFRS 9'un hükümleri geçerli olmaktadır. Buna göre, ticari ve diğer alacaklar değerleme gününde etkin faiz yöntemi kullanılarak itfa edilmiş maliyeti üzerinden ölçülmektedir. BOBİ FRS'de ticari ve diğer alacakların ilk muhasebeleştirmesinde itibari değer veya itfa edilmiş maliyet ölçüsü esas alınmaktadır. Bu iki farklı ölçümün ayrılmasındaki temel belirleyici unsur ise vade süresidir. Vade süresi bir yılı aşmayan ticari ve diğer alacaklar itibari değer ile, vade süresi bir yılı aşan ticari ve diğer alacaklar ise TFRS 9'da olduğu gibi itfa edilmiş maliyet ile ölçülmektedir (BOBİ FRS, Md. 9.8).

\section{- Borçlanma araçları:}

Borçlanma araçlarının ilk muhasebeleştirmesi TFRS 9'a göre gerçeğe uygun değer üzerinden yapılmaktadır. Söz konusu araçların edinimi ile doğrudan ilişkilendirilebilen işlem maliyetleri ise gerçeğe uygun değere ilave edilmektedir (TFRS 9, Md. 5.1.1). BOBİ FRS'de ise ilk muhasebeleştirme işlem fiyatı üzerinden yapılmakta; aracılara, danışmanlara vb. ödenen ücretler, düzenleyici kurumlar tarafından alınan harçlar gibi işlem maliyetleri de işlem fiyatına dahil edilmektedir (BOBİ FRS, Md. 9.12).

TFRS 9'a göre borçlanma araçları; ilgili finansal varlığın yönetimi için işletmenin kullandığı iş modeline ve finansal varlığın sözleşmeye bağlı nakit akışlarının özelliklerine göre dönem sonlarında itfa edilmiş maliyetle veya gerçeğe uygun değerle ölçülmektedir (TFRS 9, Md. 4.1.1). TFRS 9'a göre borçlanma araçları; sözleşmeye bağlı nakit akışlarının tahsil edilmesini amaçlayan bir iş modeli kapsamında elde tutuluyorsa itfa edilmiş maliyetle, sözleşmeye bağlı nakit akışlarının tahsil edilmesini ve ilgili varlığın satılmasını amaçlayan bir iş modeli kapsamında elde tutuluyorsa gerçeğe uygun değerle ölçülmektedir. Gerçeğe uygun değerle ölçülmesi halinde gerçeğe uygun değer fark1 diğer kapsamlı gelire yansitılarak ölçülmektedir (TFRS 9, Md. 4.1.2. ve 4.1.2A). BOBİ FRS'de sonraki ölçümler için TFRS 9'daki gibi bir sınıflandırmaya yer verilmemekle birlikte borçlanma araçlarının itfa edilmiş maliyet ile ölçülmesi hükmü getirilmiştir (BOBİ FRS, Md. 9.11).

\section{- Özkaynak Araçlarındaki Yatırımlar:}

TFRS 9 standardı uyarınca özkaynağa dayalı finansal varlıklar ilk muhasebeleştirmede gerçeğe uygun değeri üzerinden ölçülür. Söz konusu finansal varlıkların izleyen dönemlerde gerçeğe uygun değerinde meydana gelen değişiklikler kar veya zarar olarak raporlandığından ilk muhasebeleştirmedeki işlem maliyetleri kar veya zarar olarak sinıflandirılır (Örten vd., 2017: 435). Bununla birlikte; ilk muhasebeleştirmede, ticari (alım-satım) amaçla elde tutulmayan veya TFRS 3 İŞLETME BİRLEŞMELERİ standardının uygulandığı bir işletme birleşmesinde edinen işletmenin finansal tablolarına aldığı bir şarta bağlı bedel niteliğinde olmayan, bu standart kapsamındaki bir özkaynak aracına yapılan yatırımın gerçeğe uygun değerindeki sonraki değişikliklerin diğer kapsamlı gelirde sunulması konusunda, geri dönülemeyecek bir tercihte bulunulabilir (TFRS 9, Md. 5.7.5). 
BOBİ FRS'de; özkaynak araçlarındaki yatırımlar, borsada ve/veya teşkilatlanmış diğer piyasalarda işlem görüp görmediklerine bağlı olarak farklı ş̧ekillerde ölçülmektedir. Borsada ve/veya teşkilatlanmış diğer piyasalarda işlem gören özkaynak araçları, ilk muhasebeleştirmede işlem fiyatından ölçülerek işlem maliyetleri kar veya zarara yansıtılır. Bu özkaynak araçları raporlama tarihinde ise gerçeğe uygun değerleri (piyasa değeri) üzerinden ölçülür ve ortaya çıkan değer farkları "Finansal Yatırımlar Değer Artış Kazançları" veya "Finansal Yatırımlar Değer Azalış Zararları" kalemlerinde kar veya zarara yansitılır (BOBİ FRS, Md. 9.20). Borsada ve/veya teşkilatlanmış diğer piyasalarda işlem görmeyen özkaynak araçları ise, ilk muhasebeleştirmede işlem fiyatları ve işlem maliyetlerinin toplamından oluşan maliyet bedelinden ölçülmektedir. Bu özkaynak araçları sonraki raporlama tarihlerinde maliyet bedelinden varsa değer düşüklüğü zararları düşülerek ölçülmektedir (BOBİ FRS, Md. 9.21).

\section{- Diğer Finansal Varlıklar:}

Diğer finansal araçlardan, nakden net olarak yerine getirilemeyen ve taahhüt yerine getirildiğinde borçlanma aracı tanımını karşılayan kredi alınmasına ilişkin taahhütler maliyet bedeliyle ölçülür. Bu kapsamda bu tür taahhütler ilk kayda alma sırasında, işlem fiyatlarına işlem maliyetleri de dâhil edilerek maliyet bedeli üzerinden ölçülür. Sonraki ölçümlerde varsa değer düşüklüğü zararları hesaplanarak maliyet bedelinden düşülür (BOBİ FRS, Md. 9.25). Diğer yandan; bu özellikleri taşıyan kredi alınmasına ilişkin taahhütler dışında kalan diğer finansal araçlar (türev finansal araçlar) ise hem ilk kayda almada hem de sonraki değerlemelerde gerçeğe uygun değerleri üzerinden ölçülerek ölçüm farkları kâr veya zarara yansıtılır. İlk kayda almada katlanılan işlem maliyetleri ise doğrudan kar veya zarara yansitılır (BOBİ FRS, Md. 9.26).

\subsubsection{Sonraki Ölçümlere İlişkin Açıklamalar}

Finansal varlıkların ve bu sınıflamada yer alan ticari ve diğer alacakların dönem sonundaki değer düşüklüğünün tespitinde, TFRS 9 "beklenen kredi zararı" yaklaşımı ilke olarak sunmaktadır (TFRS 9, Md. 5.5). BOBİ FRS'de ise böyle bir yaklaşım tanımlanmamış olup, makul bir gerekçeye dayanarak tahsili şüpheli hale gelen ticari ve diğer alacaklar şüpheli alacaklar olarak sınıflandırılmaktadır (BOBİ FRS, Md. 9.10). Bu yaklaşım “gerçekleşen kredi zararı” olarak da tanımlanmaktadır (BOBİ FRS, Md. 9.16).

BOBİ FRS'ye göre bir finansal varlığın değer düşüklüğü aşağıdaki gibi hesaplanmaktadır (BOBİ FRS, Md. 9.37):

- İtibari değeri üzerinden ölçülen alacaklar için değer düşüklüğü zararı, alacağın defter değeri ile alacağın vadesinde tahsil edilmesi beklenen en gerçekçi tahmini tutar arasındaki farktır.

- Maliyet bedelinden ölçülen finansal araçlar için değer düşüklüğü zararı, varlığın defter değeri ile varlığın raporlama dönemi sonunda satılmış olması durumunda elde edilecek en gerçekçi tahmini tutar arasındaki farktır.

- İtfa edilmiş değeri üzerinden ölçülen bir finansal araç için değer düşüklüğü zararı, varlığın defter değeri ile varlığa ilişkin tahmini nakit akışlarının, başlangıçtaki etkin faiz oranı kullanılarak bugüne indirgenmiş değeri arasındaki farktır. Finansal aracın değişken bir faiz oranına sahip olması durumunda, değer düşüklüğü zararının 
ölçülmesi açısından indirgemede kullanılacak faiz oranı, sözleşmeye göre belirlenen cari etkin faiz oranıdır.

Değer düşüklüğüne dair gözlemlenebilir bir kanıt bulunduğunda, değer düşüklüğü zararı ticari alacaklar için "Esas Faaliyetlerden Diğer Giderler" kalemine, diğer finansal varlıklar için ise "Finansal Yatırımlar Değer Azalış Zararları" kalemine yansıtılır (BOBİ FRS, Md. 9.33). Daha sonraki bir dönemde değer düşüklüğü zararının iptali söz konusu olduğunda iptal edilen tutar ticari alacaklar için "Esas Faaliyetlerden Diğer Gelirler" kalemine, diğer finansal varlıklar için ise "Finansal Yatırımlar Değer Artış Kazançları" kalemine yansitılır (BOBİ FRS, Md. 9.38).

\subsection{TFRS 9 Standardı ve BOBİ FRS Standardına Göre Finansal Varlıklara İlişkin Muhasebe Uygulamaları}

\section{- Örnek 1: Ticari Alacaklarda İlk Muhasebeleştirme ve Ölçüm}

01.12.2016 tarihinde \%18 KDV hariç 500.000TL peşin değerli ticari mal vadeli olarak satılmıştır. Satış karşılığında \%18 KDV dahil 649.000TL itibari değerli ve vadesine 3 ay (90 gün) bulunan bir alacak senedi alınmıştır. Bilanço tarihi itibariyle TCMB iskonto oran $1 \% 10$ 'dur.

- TFRS 9'a göre ilk muhasebeleştirme ve değerlemeye ilișkin muhasebe kayıtları aşağıldaki gibi olacaktır: (Vadesi bir yılın altında olan vadeli satışlarda, önemli bir finansman unsuru içermiyorsa ayrıştırma yapılmayabilir.)

Ticari malın KDV hariç vadeli satış fiyatı $=649.000 / 1,18=550.000 \mathrm{TL}$ olacaktır.

\begin{tabular}{|c|c|c|c|}
\hline $\begin{array}{c}\text { Mad. } \\
\text { No }\end{array}$ & AÇIKLAMA & BORÇ & ALACAK \\
\hline & $\begin{array}{l}\text { 121 ALACAK SENETLERİ HESABI } \\
600 \text { YURT İÇI SATIŞLAR HS. } \\
\text { 391 HESAPLANAN KDV HS. } \\
\text { 122 ALACAK S. REESK. HS. } \\
\text { İlk muhasebeleştirme kaydı. }\end{array}$ & 649.000 & $\begin{array}{c}500.000 \\
99.000 \\
50.000\end{array}$ \\
\hline
\end{tabular}

50.000TL tutarındaki faiz gelirinin bir kısmı (bir aylık) Aralık ayı içerisinde, kalan kısmı (iki aylık) ise izleyen yıl Ocak ve Şubat aylarının faiz geliri olarak tahakkuk etmelidir. Söz konusu tutarları hesaplayabilmek için etkin faiz oranı hesaplanmalıdır.

Etkin Faiz Oran $1=(550.000 / 500.000)^{1 /(3 / 12)}-1=0,4641=\% 46,41$ olarak hesaplanacaktır.

Etkin faiz oranından yola çıkarak alacak senedinin bilanço tarihindeki 2 ay için itfa edilmiş maliyeti 550.000/(1+0,4641 $)^{2 / 12}=516.140 \mathrm{TL}$ olarak hesaplanacaktır. TFRS 9'a göre bilanço tarihindeki itfa edilmiş maliyet ile peşin değer arasındaki fark $(516.140 \mathrm{TL}-500.000 \mathrm{TL}=16.140 \mathrm{TL})$ faiz geliri olarak kaydedilmelidir. Kayıt ise aşağıdaki gibi olacaktır. 


\begin{tabular}{|c|c|c|c|}
\hline $\begin{array}{c}\text { Mad. } \\
\text { No }\end{array}$ & AÇIKLAMA & BORÇ & ALACAK \\
\hline & $\begin{array}{l}\text { 642 FAİZ GELIRLERİ HES. } \\
\text { ALACAK SEleme kaydı. }\end{array}$ & 16.140 & 16.140 \\
\hline
\end{tabular}

- BOBI FRS'ye göre ilk muhasebeleștirme ve değerlemeye ilișkin muhasebe kayıtları aşağıdaki gibi olacaktır:

\begin{tabular}{|c|c|c|c|}
\hline $\begin{array}{c}\text { Mad. } \\
\text { No }\end{array}$ & AÇIKLAMA & BORÇ & ALACAK \\
\hline & $\begin{array}{ll}121 \text { ALACAK SENETLERİ HESABI } \\
\text { HS. } & 600 \text { YURT İÇİ SATIŞLAR } \\
\text { HS. } & 391 \text { HESAPLANAN KDV } \\
\text { İlk muhasebeleștirme kaydi. }\end{array}$ & 649.000 & $\begin{array}{c}550.000 \\
99.000\end{array}$ \\
\hline
\end{tabular}

BOBİ FRS'ye göre yapılan kayıtta, ticari alacağın edinildiği tarihteki vade süresi bir yılın altında olduğundan faiz tutarı ayrıştırılmamıştır. Dolayısıyla, vadeli satış tutarının tamamı hasılat olarak satış gelirlerine kaydedilmiştir.

BOBİ FRS'ye göre 649.000TL itibari değerli alacak senedi edinim tarihi itibariyle vadesi bir yılın altında olduğu için bilanço tarihinde itibari değerle değerlenecektir. Bu durumda, dönem sonu itibariyle herhangi bir hesaplama ve muhasebe kaydı yapılmayacaktır. Daha açık ifadeyle, BOBİ FRS kapsamında edinim tarihi itibariyle vadesi bir yılın altında kalan ticari ve diğer alacaklar için reeskont hesaplaması yapılmayacaktır. Buradaki temel varsayım; TFRS 9'da olduğu gibi, vadesi bir yılın altında kalan ticari alacakların içerdiği finansman unsurunun göz ardı edilebilecek kadar düşük olduğunun kabul edilmesi ile ilgilidir.

Eğer bu örnekteki alacak senedinin edinim tarihindeki vadesi bir yıldan daha uzun olsaydı, BOBİ FRS kapsamında yapılması gereken ilk muhasebeleştirme ve değerlemeye ilişkin hesaplamalar ile muhasebe kayıtları, TFRS 9 hükümlerine göre yapılan uygulamanın benzeri bir şekilde yapılacaktır. Diğer bir ifadeyle, alacak senedinin edinim tarihindeki vadesi bir yıldan daha uzun olması durumundaki ölçüm itfa edilmiş maliyet ile yapılacaktır. Bu durumda etkin faiz yöntemine göre hesaplanan faiz tutarı kar veya zarar tablosunda "Esas Faaliyetlerden Diğer Gelirler" veya "Esas Faaliyetlerden Diğer Giderler" kalemlerinde; diğer alacak ve borçlara ilişkin etkin faiz yöntemine göre hesaplanan faiz tutarı ise "Faiz, Kâr Payı vb. Gelirler" veya "Faiz vb. Giderler" kalemlerinde kayıt altına alınacaktır.

- Örnekteki vadenin 3 ay (90 gün) değil de 15 ay (450 gün) olmasl durumunda BOBI FRS kapsaminda yapılmasl gereken hesaplamalar ve muhasebe kayıtlart așağıdaki gibi olacaktır: 


\begin{tabular}{|c|c|c|c|}
\hline $\begin{array}{c}\text { Mad. } \\
\text { No }\end{array}$ & AÇIKLAMA & BORÇ & ALACAK \\
\hline & $\begin{aligned} 121 \text { ALACAK SENETLERİ HESABI } \\
\text { 600 YURT İĊI SATIŞLAR HS. } \\
\text { 391 HESAPLANAN KDV HS. } \\
\text { 122 ALACAK S. REESK. HS. }\end{aligned}$ & 649.000 & $\begin{array}{c}500.000 \\
99.000 \\
50.000\end{array}$ \\
\hline
\end{tabular}

50.000TL tutarındaki toplam faiz bu sefer 15 aylık bir vade üzerinden hesaplamaya tabi tutularak etkin faiz oranı hesaplanacaktır.

Etkin Faiz Oran $1=(550.000 / 500.000)^{1 /(15 / 12)}-1=0,0792=\% 7,92$ olarak hesaplanacaktır.

Etkin faiz oranından yola çıkarak alacak senedinin bilanço tarihindeki 14 ay için itfa edilmiş maliyeti $550.000 /(1+0,0792)^{14 / 12}=503.187 \mathrm{TL}$ olarak hesaplanacaktır. BOBİ FRS'ye göre bilanço tarihindeki itfa edilmiş maliyet ile peşin değer arasındaki fark $(503.187 \mathrm{TL}-500.000 \mathrm{TL}=3.187 \mathrm{TL})$ faiz geliri olarak kaydedilmelidir. Kayıt ise aşağıdaki gibi olacaktır.

\begin{tabular}{|c|c|c|c|}
\hline $\begin{array}{c}\text { Mad. } \\
\text { No }\end{array}$ & AÇIKLAMA & BORÇ & ALACAK \\
\hline & $\begin{array}{r}122 \text { ALACAK SEN. REESK. HS. } \\
\text { XXX ESAS FAALIYYTLERDEN } \\
\text { DİGER GELİRLER HESABI } \\
\text { Değerleme kaydı. }\end{array}$ & 3.187 & 3.187 \\
\hline
\end{tabular}

Örneğe göre alacak senedinin vadesi 2018 y1lı Şubat ayı sonudur. Bu durumda, 2017 yılının dönem sonu itibariyle de değerleme yapılması gerekmektedir. 2017 y1lı bilanço tarihinde kalan vade süresi iki ay olacağından bu tarihteki itfa edilmiş maliyet hesaplanmalıdır. Ancak bulunacak tutardan 2016 yılı dönem sonu itibariyle kar veya zarar tablosuna aktarılan tutar düşülmelidir.

$550.000 /(1+0,0792)^{2 / 12}=543.055$ TL olarak hesaplanacaktır. BOBİ FRS'ye göre bilanço tarihindeki itfa edilmiş maliyet ile bir önceki bilanço tarihinin itfa edilmiş maliyet değeri arasındaki fark $(543.055 \mathrm{TL}-503.187 \mathrm{TL}=39.868 \mathrm{TL})$ faiz geliri olarak kaydedilmelidir. Kayıt ise aşağıdaki gibi olacaktır.

\begin{tabular}{|c|c|c|c|}
\hline $\begin{array}{c}\text { Mad. } \\
\text { No }\end{array}$ & AÇIKLAMA & BORÇ & ALACAK \\
\hline & $\begin{array}{l}\text { XXX ESAS FAALIYETLERDEN } \\
\text { DİĞER GELİRLER HESABI } \\
\text { Değerleme kaydı. }\end{array}$ & 39.868 & 39.868 \\
\hline
\end{tabular}

Geriye kalan ve henüz gelir olarak kaydedilmemiş olan faiz tutarı ise (550.000TL $-543.055 \mathrm{TL}=6.945 \mathrm{TL}$ ) alacak senedinin vadesi geldiği tarih itibariyle gelir olarak kaydedilecektir. Vade tarihinde yapılması gereken kayıt aşağıdaki gibi olacaktır: 


\begin{tabular}{|c|c|c|c|}
\hline $\begin{array}{c}\text { Mad. } \\
\text { No }\end{array}$ & AÇIKLAMA & BORÇ & ALACAK \\
\hline & $\begin{array}{l}102 \text { BANKALAR HESABI } \\
122 \text { ALACAK SEN. REESK. HS. } \\
\text { 121 ALACAK SENETLERİ HS. } \\
\text { XXX ESAS FAALIYETLERDEN } \\
\text { DİĞER GELİRLER HESABI } \\
\text { Alacak senedinin vadesinde tahsil edilmesi kaydi. }\end{array}$ & $\begin{array}{c}649.000 \\
6.945\end{array}$ & $\begin{array}{c}649.000 \\
6.945\end{array}$ \\
\hline
\end{tabular}

\section{- Örnek 2: Ticari Alacaklarda Değer Düşüklüğ̈̈̈}

31.12.2016 tarihi itibariyle işletmenin ticari alacak tutar1 20.000TL ve 50.000TL olan iki adet alacak senedi bulunmaktadır. 20.000TL tutarındaki alacak senedinin vadesi 30 günden fazla geçmiş ve kredi riski \%5 olarak belirlenmiştir. 50.000TL tutarındaki alacak senedinin vadesine ise bilanço tarihi itibariyle iki ay bulunmakta (toplam vade süresi bir yılın altındadır) ve alacak senedinin 30.11.2016 tarihindeki peşin değeri 46.826TL'dir. Söz konusu alacak senedi için hesaplanmış olan etkin faiz oranı yıllık \%30'dur. Vadesi geçmemiş alacak senetleri için uygulanan kredi riski oranı \%0,5'tir. Bilanço tarihi itibariyle TCMB iskonto oran $1 \% 10$ 'dur.

\section{- TFRS 9'a göre beklenen kredi zararı aşağıdaki gibi hesaplanacaktır:}

Vadesi gelmemiş alacak senedinin bilanço günündeki itfa edilmiş maliyeti $50.000 /(1+0,30)^{2 / 12}=47.861 \mathrm{TL}$ olarak hesaplanacaktır. (Alacak senedinin bilanço tarihine kadar geçen zamanda tahakkuk eden faiz geliri 47.861 $-46.826=1.035 \mathrm{TL}$ 'dir.) Yine aynı alacağın itfa edilmemiş beklenen kredi zararı 50.000TL $\times 0,005=250 \mathrm{TL}$ 'dir. Buna göre bilanço günündeki itfa edilmiş beklenen kredi zararı $250 /(1+0,30)^{2 / 12}=$ 239TL olarak hesaplanacaktır.

Vadesi geçmiş alacak senedinin bilanço tarihindeki beklenen kredi zararı $20.000 \times 0,05=1.000 \mathrm{TL}$ olarak hesaplanacaktır.

Beklenen kredi zararları toplamı $239+1.000=1.239$ TL beklenen kredi zararı karşılığı olarak kayıtlara alınacaktır.

\begin{tabular}{|c|c|c|c|}
\hline $\begin{array}{c}\text { Mad. } \\
\text { No }\end{array}$ & AÇIKLAMA & BORÇ & ALACAK \\
\hline & $\begin{array}{l}\text { 122 ALACAK SEN. REESK. HS. } \\
\text { 642 FAİZ GELİRLERİ HES. } \\
\text { Değerleme kaydı. }\end{array}$ & 1.035 & 1.035 \\
\hline & $\begin{array}{l}\text { 654 KARŞILIK GİDERLERİ HESABI } \\
\text { Beklenen Ticari Alacak Kredi Zararları } \\
\text { 129 ŞÜPH. TİCARİ ALAC. K. } \\
\text { Beklenen Ticari Alacak Kredi } \\
\text { Zarar Karşılıkları }\end{array}$ & 1.239 & 1.239 \\
\hline
\end{tabular}


- BOBI FRS'ye göre gerçekleșen kredi zararı așağıdaki gibi hesaplanacaktır:

Örnek 2'de yer alan vadesi geçmemiş alacak senedinin edinim tarihi ile tahsil edileceği tarih arasındaki süre bir yılın altında olduğundan itibari değerle değerlenecektir. Diğer yandan vadesi geçmiş ve şüpheli hale gelmiş bulunan 20.000TL tutarındaki alacak senedini için karşılık ayrılmak istenmektedir. Alacak senedi itibari değerle değerlendiğinden, değer düşüklüğü ile ilgili kanıtlar araştırılmış ve \%20 oranında karşılık ayrılması gerektiğine dair makul şüpheye sahip gözlemlenebilir kanıtlar elde edilmiştir. Buna göre $20.000 \times 0,20=4.000 \mathrm{TL}$ tutarında değer düşüklüğü zararı kaydedilmelidir.

\begin{tabular}{|c|c|c|c|}
\hline $\begin{array}{c}\text { Mad. } \\
\text { No }\end{array}$ & AÇIKLAMA & BORÇ & ALACAK \\
\hline & $\begin{array}{l}\text { XXX ESAS FAALIYYETLERDEN } \\
\text { DİĞER GİDERLERİ HESABI } \\
129 \text { ŞÜPH. TİCARİ ALAC. K. }\end{array}$ & 4.000 & 4.000 \\
\hline
\end{tabular}

- Örnek 3: Sözleşmeye Bağlı Nakit Akışlarının Tahsil Edilmesini Amaçlayan Bir Isş Modeli Kapsamında Elde Tutulan Borçlanma Araçlarında İk Muhasebeleştirme ve Ölçüm

İşletme 01.01.2016 tarihinde 49.500TL karşılığında sözleşmeye bağlı nakit akışlarının tahsil edilmesini amaçlayan bir iş modeli kapsamında elde bulundurmak amacıyla 5 yıl vadeli devlet tahvili satın almıştır. Satın alınan tahvillerin itibari değeri ise $60.000 \mathrm{TL}$ ve y1llık faiz oranı \%5'tir. Alım için 500TL işlem maliyetine katlanılmıştır.

- TFRS 9'a göre ilk muhasebeleștirme ve değerlemeye ilișkin muhasebe kayttlar așağıldaki gibi olacaktır:

TFRS 9 standardı borçlanma araçlarının ilk muhasebeleştirmesinde işlem maliyetleri dahil edilmiş gerçeğe uygun değeri kullanırken, BOBİ FRS'ye göre borçlanma araçlarının ilk muhasebeleştirilmesinde işlem maliyetleri ilave edilmiş işlem fiyatı kullanılmaktadır. Bununla birlikte, ilk muhasebeleştirmede işlem fiyatının genellikle gerçeğe uygun değere eşit olduğu kabul edildiğinden, ilk muhasebeleştirme kaydında TFRS 9 ile BOBİ FRS açısından bir farklılık oluşmayacaktır.

İşlem fiyat $1=49.500 \mathrm{TL}$

İşlem maliyeti $=500 \mathrm{TL}$

\begin{tabular}{|c|c|c|c|}
\hline $\begin{array}{c}\text { Mad. } \\
\text { No }\end{array}$ & AÇIKLAMA & BORÇ & ALACAK \\
\hline & $\begin{array}{l}112 \text { KAMU KESIMM TAHVIL SENET } \\
\text { VE BONOLARI HESABI } \\
\text { İtfa edilmiş maliyeti üzerinden ölçülen finansal } \\
\text { varlıklar } \\
\text { I02 BANKALAR HESABI } \\
\text { İlk muhasebeleştirme kaydı. }\end{array}$ & 50.000 & 50.000 \\
\hline
\end{tabular}


Sözleşmeye bağlı nakit akışlarının tahsil edilmesini amaçlayan bir iş modeli kapsamında elde tutulan borçlanma araçları gerek TFRS 9'a göre ve gerekse BOBİ FRS'ye göre itfa edilmiş maliyeti üzerinden ölçülmektedir. Bu sebeple, Örnek 3 kapsamında aşağıda sunulan uygulama, hem TFRS 9 için, hem de BOBİ FRS için uygun bir örnek oluşturmaktadır.

İşletmenin tahvilleri alması halinde 2016 yılı başında 50.000TL nakit çıkışı gerçekleşecek, dönem sonunda ise 3.000TL $(60.000 \times 0,05)$ faiz tahakkuk edecektir. Tahvilin vadesi 5 yıl olduğundan ve işletmenin tahvilleri nakit akışlarını tahsil etmeyi amaçlayan bir iş modeli kapsamında elde bulunduruyor olmasından sebeple, 5 y1l boyunca aynı tutarda faizin tahakkuk edeceği varsayılmaktadır. Buna göre, varsayılan nakit akışları için etkin faiz yönteminden yararlanılarak etkin faiz oranı hesaplanacak ve tahvilleri dönem sonlarında itfa edilmiş maliyetleri üzerinden ölçülecektir.

Varsayılan nakit akışlarından hareketle hesaplanan etkin faiz oranı (iç verim oran1) 0,0932 olarak bulunacaktır. Buna göre itfa edilmiş maliyet tablosu aşağıdaki gibi düzenlenecektir.

Tablo 2. İtfa Edilmiş Maliyet Tablosu

\begin{tabular}{|c|c|c|c|c|}
\hline Tarih & $\begin{array}{c}\text { Dönem } \\
\text { Başında İtfa } \\
\text { Edilmiş } \\
\text { Maliyet (A) }\end{array}$ & $\begin{array}{c}\text { Faiz Geliri (B) } \\
(\mathbf{A} \times \mathbf{0 , 0 9 3 2})\end{array}$ & $\begin{array}{c}\text { Nakit Akışı } \\
(\mathbf{C})\end{array}$ & $\begin{array}{c}\text { Dönem } \\
\text { Sonunda İtfa } \\
\text { Edilmiş } \\
\text { Maliyet (A+B- } \\
\mathbf{C})\end{array}$ \\
\hline 31.12 .2016 & 50.000 & $4.660,287$ & 3.000 & $51.660,287$ \\
\hline 31.12 .2017 & $51.660,287$ & 4815,035 & 3.000 & $53.475,323$ \\
\hline 31.12 .2018 & $53.475,323$ & 4984,207 & 3.000 & $55.459,530$ \\
\hline 31.12 .2019 & $55.459,530$ & $5.169,147$ & 3.000 & $57.628,676$ \\
\hline 31.12 .2020 & $57.628,676$ & $5.371,324$ & $60.000+3.000$ & - \\
\hline
\end{tabular}

\begin{tabular}{|c|c|c|c|}
\hline $\begin{array}{c}\text { Mad. } \\
\text { No }\end{array}$ & AÇIKLAMA & BORÇ & ALACAK \\
\hline & $\begin{array}{l}112 \text { KAMU KESIM TAHVİL SENET } \\
\quad \text { VE BONOLARI HESABI } \\
\text { İtfa edilmiş maliyeti üzerinden ölçülen finansal } \\
\text { varlıklar } \\
102 \text { BANKALAR HESABI } \\
\quad 642 \text { FAİZ GELİRLERİ HESABI } \\
2016 \text { yılı faiz geliri tahakkuku. }\end{array}$ & 1.660 & 4.660 \\
\hline
\end{tabular}




\begin{tabular}{|c|c|c|c|}
\hline $\begin{array}{c}\text { Mad. } \\
\text { No }\end{array}$ & AÇIKLAMA & BORÇ & ALACAK \\
\hline & $\begin{array}{l}112 \text { KAMU KESIMM TAHVİL SENET } \\
\text { VE BONOLARI HESABI } \\
\text { İtfa edilmiş maliyeti üzerinden ölçülen finansal } \\
\text { varlıklar } \\
102 \text { BANKALAR HESABI } \\
\text { 642 FAİZ GELIRLERİ HESABI } \\
2017 \text { yılı faiz geliri tahakkuku. }\end{array}$ & 1.815 & 4.815 \\
\hline
\end{tabular}

\begin{tabular}{|c|c|c|c|}
\hline $\begin{array}{c}\text { Mad. } \\
\text { No }\end{array}$ & AÇIKLAMA & BORÇ & ALACAK \\
\hline & $\begin{array}{l}112 \text { KAMU KESIMM TAHVİL SENET } \\
\text { VE BONOLARI HESABI } \\
\text { İtfa edilmiş maliyeti üzerinden ölçülen finansal } \\
\text { varlıklar } \\
102 \text { BANKALAR HESABI } \\
\text { 642 FAİZ GELİRLERİ HESABI } \\
2018 \text { yılı faiz geliri tahakkuku. }\end{array}$ & 1.984 & 4.984 \\
\hline
\end{tabular}

\begin{tabular}{|c|c|c|c|}
\hline $\begin{array}{c}\text { Mad. } \\
\text { No }\end{array}$ & AÇIKLAMA & BORÇ & ALACAK \\
\hline & $\begin{array}{l}112 \text { KAMU KESIM TAHVİL SENET } \\
\text { VE BONOLARI HESABI } \\
\text { İtfa edilmiş maliyeti üzerinden ölçülen finansal } \\
\text { varlıklar } \\
102 \text { BANKALAR HESABI } \\
\quad 642 \text { FAİZ GELIRLERİ HESABI } \\
2019 \text { yılı faiz geliri tahakkuku. }\end{array}$ & 2.169 & 5.169 \\
\hline
\end{tabular}

\begin{tabular}{|c|c|c|c|}
\hline $\begin{array}{c}\text { Mad. } \\
\text { No }\end{array}$ & AÇIKLAMA & BORÇ & ALACAK \\
\hline & 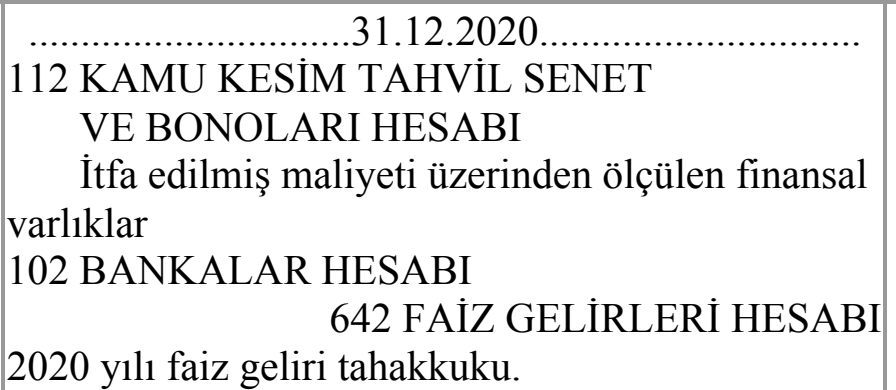 & 3.000 & 5.372 \\
\hline
\end{tabular}




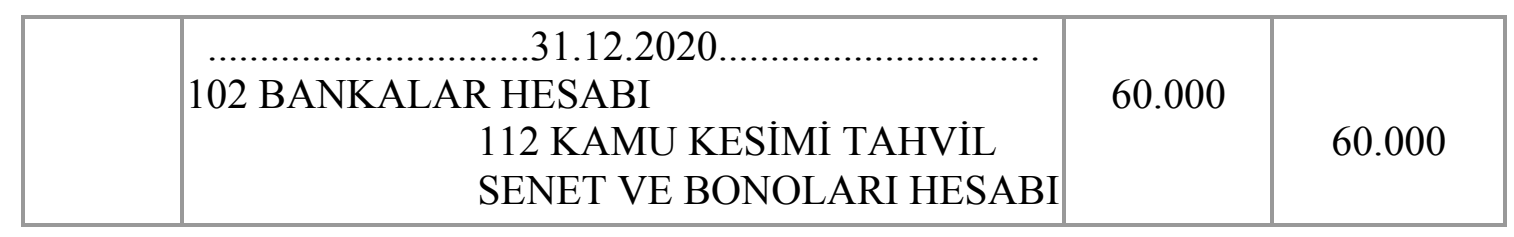

- Örnek 4: Sözleşmeye Bağlı Nakit Akışlarının Tahsil Edilmesini ve Satılmasını Amaçlayan Bir İş Modeli Kapsamında Elde Tutulan Borçlanma Araçlarında İk Muhasebeleştirme ve Ölçüm

Örnek 3'te yer alan uygulamanın sözleşmeye bağlı nakit akışlarının tahsil edilmesini ve satışını amaçlayan bir iş modeli kapsamında elde bulundurmak amacına yönelik olarak uygulanması halinde BOBİ FRS açısından Örnek 3'te sunulan uygulama aynen geçerli olacaktır. Çünkü BOBİ FRS'de borçlanma araçlarının bir iş modeli kapsamında ne şekilde elde bulundurulacağına yönelik herhangi bir ayrıma gidilmemiş olup, tüm borçlanma araçlarının itfa edilmiş maliyet ile ölçülmesi gerektiği belirtilmiştir. Ancak TFRS 9 açısından ilk muhasebeleştirmesinin ardından söz konusu borçlanma aracının değerleme gününde gerçeğe uygun değer üzerinden değerlenmesi ve değerleme farkının diğer kapsamlı gelirde raporlanması gerekmektedir.

- Örnek 3'teki tahvillerin sözleșmeye bă̆ll nakit aklșlarının tahsil edilmesini ve satıșını amaçlayan bir iș modeli kapsamında elde bulundurması halinde; 31.12.2016 tarihi itibariyle tahvillerin piyasa değerinin 52.500TL olmasl durumunda, ilgili TFRS 9'a göre bilanço tarihinde yapılması gereken kayıt aşağıdaki gibi olacaktır:

\begin{tabular}{|c|c|c|c|}
\hline $\begin{array}{c}\text { Mad. } \\
\text { No }\end{array}$ & AÇIKLAMA & BORÇ & ALACAK \\
\hline & $\begin{array}{l}112 \text { KAMU KESIMM TAHVİL SENET } \\
\text { VE BONOLARI HESABI } \\
\text { GUD farkı diğer kapsamlı gelire yansitılarak } \\
\text { ölçülen finansal varlıklar } \\
102 \text { BANKALAR HESABI } \\
\text { 642 FAİZ GELİRLERİ HESABI } \\
\text { 526 FINANSAL VARLIK } \\
\text { DEĞERLEME FARKLARI } \\
\text { 2016 yılı gerçeğe uygun değerdeki değişimin ve faiz } \\
\text { gelirinin kaydedilmesi. }\end{array}$ & 2.500 & $\begin{array}{l}3.000 \\
2.500\end{array}$ \\
\hline
\end{tabular}

TFRS 9'a göre, gerçeğe uygun değer farkı diğer kapsamlı gelire yansıtılarak ölçülen finansal varlıkların satılması halinde, satıldığı tarihte ölçülen defter değeri ile elde edilen tutar arasında ortaya çıkan fark kar veya zarar olarak raporlanmaktadır (TFRS 9, Md. 3.2.12).

- Örnek 3'te yer alan tahvillerde bilanço tarihi itibariyle oluşan gerçeğe uygun değer farkının diğer kapsamlı gelire yansitılarak ölçülmesinden sonra, izleyen yıl içerisinde 58.000TL elden çıkartılması durumunda TFRS 9'a göre yapılması gereken kayıt aşağıldaki gibi olacaktır: 


\begin{tabular}{|c|c|c|c|}
\hline $\begin{array}{c}\text { Mad. } \\
\text { No }\end{array}$ & AÇIKLAMA & BORÇ & ALACAK \\
\hline & $\begin{array}{c}102 \text { BANKALAR HESABI } \\
526 \text { FINANSAL VARLIK } \\
\text { DEĞERLEME FARKLARI } \\
112 \text { KAMU KESIM T. SENET } \\
\text { VE BONOLARI HESABI } \\
\text { GUD farkı diğer kapsamlı gelire } \\
\text { yansıtılarak ölçülen f. varlıklar } \\
\text { 645 MENKUL KIYMET SATIŞ } \\
\text { KARLARI HESABI } \\
2017 \text { yılında finansal varlığın elden çıkartılması. }\end{array}$ & $\begin{array}{c}58.000 \\
2.500\end{array}$ & 52.500 \\
\hline
\end{tabular}

\section{Ölçümü}

- Örnek 5: Özkaynak Araçlarındaki Yatırımların İlk Muhasebeleştirmesi ve

İşletme 10.12.2015 tarihinde, halka açık bir piyasada işlem görmekte olan ve özkaynak araçlarındaki yatırım olarak sınıflandırdığı imtiyazlı hisse senetlerini 95.500TL'ye satın almış ve bu işlem için 500TL komisyon ödemiştir. Satın alınan imtiyazlı hisse senetlerinin 31.12.2015 tarihindeki piyasa değeri $102.000 \mathrm{TL}$ ve 31.12.2016 tarihindeki piyasa değeri 90.000TL'dir. Satın alınan imtiyazlı hisse senetleri 20.02.2017 tarihinde 110.000TL'ye elden çıkartılmıştır.

Örnek 5'deki işlemleri BOBİ FRS ile karşılaştırılabilmesi için, ilgili finansal varlığın gerçeğe uygun değer farkı kar veya zarara yansıtılarak sınıflandırılmıştır. BOBİ FRS'de diğer kapsamlı gelirlere ilişkin bir tanımlama olmamasına karşın, TFRS 9 hükümlerine göre özkaynağa dayalı finansal varlığın alım-satım amaçlı olarak elde bulundurulmuyor olması halinde (uzun vadede elde bulundurulmak amaciyla) gerçeğe uygun değer farkı diğer kapsamlı gelirde de sınıflandırılabilmektedir.

- TFRS 9'a göre ilk muhasebeleștirmeye, değerlemeye ve satıșa ilișkin muhasebe kayıtları aşă̆ldaki gibi olacaktır:

TFRS 9'a göre, gerçeğe uygun değer farkı kar veya zarar olarak sınıflandırılan finansal varlıkların işlem maliyetleri de kar veya zararda sınıflandırılmaktadır.

\begin{tabular}{|c|c|c|c|}
\hline $\begin{array}{c}\text { Mad. } \\
\text { No }\end{array}$ & AÇIKLAMA & BORÇ & ALACAK \\
\hline & $\begin{array}{l}248 \text { DÏĞER MALİ DURAN } \\
\text { VARLIKLAR HESABI } \\
\text { GUD farkı kar veya zarara yansıtılarak } \\
\text { Ölçülen finansal varlılar } \\
653 \text { KOMISYON GIDERLERİ HESABI } \\
102 \text { BANKALAR HESABI } \\
\text { İlk muhasebelestirme kaydı. }\end{array}$ & 95.500 & 100.000 \\
\hline
\end{tabular}




\begin{tabular}{|c|c|c|c|}
\hline $\begin{array}{c}\text { Mad. } \\
\text { No }\end{array}$ & AÇIKLAMA & BORÇ & ALACAK \\
\hline & $\begin{array}{l}\text { 248 DİĞER MALİ DURAN } \\
\text { VARLIKLAR HESABI } \\
\text { GUD farkı kar veya zarara yansıtılarak } \\
\text { Ölçülen finansal varlıklar } \\
649 \text { DİĞER OLAĞAN GELİR } \\
\text { VE KARLAR HESABI } \\
\text { Değerleme kaydı. }\end{array}$ & 6.500 & 6.500 \\
\hline
\end{tabular}

\begin{tabular}{|c|c|c|c|}
\hline $\begin{array}{c}\text { Mad. } \\
\text { No }\end{array}$ & AÇIKLAMA & BORÇ & ALACAK \\
\hline & $\begin{aligned} \text { 659 DİĞER OLAĞGN GIDER } \\
\text { VE ZARARLAR HESABI } \\
\text { 248 DİĞER MALİ DURAN } \\
\text { VARLIKLAR HESABI } \\
\text { GUD farkı kar veya zarara } \\
\text { yansıtılarak ölçülen fin. v. }\end{aligned}$ & 12.000 & 12.000 \\
\hline
\end{tabular}

\begin{tabular}{|c|c|c|c|}
\hline $\begin{array}{c}\text { Mad. } \\
\text { No }\end{array}$ & AÇIKLAMA & BORÇ & ALACAK \\
\hline & $\begin{array}{l}\text { 102 BANKALAR HESABI } \\
\text { 248 DİĞER MALİ DURAN } \\
\text { VARLIKLAR HESABI } \\
\text { GUD farkı kar veya zarara } \\
\text { yansıtılarak ölçülen f. v. } \\
\text { 649 DİĞER OLAĞAN GELİR } \\
\text { VE KARLAR HESABI }\end{array}$ & 110.000 & $\begin{array}{l}90.000 \\
20.000\end{array}$ \\
\hline
\end{tabular}

- BOBI FRS'ye göre ilk muhasebeleștirmeye, değerlemeye ve satıșa ilișkin muhasebe kayıtları așağıdaki gibi olacaktır:

BOBİ FRS'ye göre, halka açık piyasada işlem gören özkaynak araçlarındaki yatırımların ilk muhasebeleştirmesinde işlem maliyetleri işlem fiyatına dahil edilmemektedir.

\begin{tabular}{|c|c|c|c|}
\hline $\begin{array}{c}\text { Mad. } \\
\text { No }\end{array}$ & AÇIKLAMA & BORÇ & ALACAK \\
\hline & $\begin{array}{l}248 \text { DİGER MALİ DURAN } \\
\text { VARLIKLAR HESABI } \\
653 \text { KOMİSYON GIDERLERİ } \\
102 \text { BANKALAR HS. } \\
\text { İlk muhasebeleştirme kaydı. }\end{array}$ & $\begin{array}{c}90.500 \\
500\end{array}$ & 100.000 \\
\hline
\end{tabular}




\begin{tabular}{|c|c|c|c|}
\hline $\begin{array}{c}\text { Mad. } \\
\text { No }\end{array}$ & AÇIKLAMA & BORÇ & ALACAK \\
\hline & $\begin{array}{c}248 \text { DİĞER MALİ DURAN } \\
\text { VARLIKLAR HESABI } \\
\text { XXX FINANSAL YATIRIMLAR } \\
\text { DEĞER ARTIŞ } \\
\text { KAZANÇLARI }\end{array}$ & 6.500 & 6.500 \\
\hline
\end{tabular}

\begin{tabular}{|c|c|c|c|}
\hline $\begin{array}{c}\text { Mad. } \\
\text { No }\end{array}$ & AÇIKLAMA & BORÇ & ALACAK \\
\hline & $\begin{array}{l}\text { XXX FINANSAL YATIRIMLAR } \\
\text { DEĞER AZALIŞ ZARARLARI } \\
248 \text { DİĞER MALİ DURAN } \\
\text { VARLIKLAR HESABI } \\
\text { Değerleme kaydı. }\end{array}$ & 12.000 & 12.000 \\
\hline
\end{tabular}

\begin{tabular}{|c|c|c|c|}
\hline $\begin{array}{c}\text { Mad. } \\
\text { No }\end{array}$ & AÇIKLAMA & BORÇ & ALACAK \\
\hline & \begin{tabular}{|c|} 
102 BANKALAR HESABI \\
248 DİĞER MALİ DURAN \\
VARLIKLAR HESABI \\
XXX FİNANSAL YATIRIMLAR \\
DEĞER ARTIŞ \\
Katıș kaydı.
\end{tabular} & 110.000 & $\begin{array}{l}90.000 \\
20.000\end{array}$ \\
\hline
\end{tabular}

- Örnek 5'teki imtiyazlı hisse senetlerinin halka açı bir piyasada ișlem görmemesi halinde BOBI FRS'ye göre ilk muhasebeleștirmeye, değerlemeye ve satıșa ilișkin muhasebe kayıtları aşă̆gdaki gibi olacaktır:

BOBİ FRS'ye göre, halka açık piyasada işlem görmeyen özkaynak araçlarındaki yatırımların ilk muhasebeleştirmesinde işlem maliyetleri işlem fiyatına dahil edilmektedir.

\begin{tabular}{|c|c|c|c|}
\hline $\begin{array}{c}\text { Mad. } \\
\text { No }\end{array}$ & AÇIKLAMA & BORÇ & ALACAK \\
\hline & $\begin{array}{l}\text { 248 DİĞER MALİ DURAN } \\
\text { VARLIKLAR HESABI } \\
102 \text { BANKALAR HS. } \\
\text { İlk muhasebeleştirme kaydı. }\end{array}$ & 100.000 & 100.000 \\
\hline
\end{tabular}

Halka açık bir piyasa işlem görmeyen özkaynak araçlarındaki yatırımların bilanço günündeki değerleme farkları TFRS 9 açısından kar veya zarara yansitılmakta ve varlığın değeri gerçeğe uygun değer üzerinden ölçülmektedir. Söz konusu ölçüm BOBİ FRS açısından ele alındığında; halka açık bir piyasa işlem görmeyen özkaynak 
araçlarındaki yatırımların maliyet bedeli üzerinden ölçüldüğü ve bilanço günüdeki değer düşüklüğü zararlarının hesaplanarak maliyet bedelinden düşüldüğü görülmektedir.

Örnek 5 için değerleme günündeki ölçüm maliyet bedeli üzerinden yapılacağından, 31.12.2015 tarihinde gerçekleşen piyasa fiyatı değer artışı kayıt altına alınmayacaktır. Ancak 31.12.2016 tarihindeki değer düşüklüğü için karşılık ayrılması gerekmektedir. BOBİ FRS kapsamında ticari alacaklar dışındaki diğer finansal varlıklardaki değer düşüklükleri "Finansal Yatırımlar Değer Azalış Zararları" kalemine yansıtılmakta; ticari alacaklar dışındaki diğer finansal varlıklar için değer düşüklüğü zararının iptal edilmesi durumunda ise iptal edilen tutar "Finansal Yatırımlar Değer Artış Kazançları" kalemine yansıtılmaktadır. Buna göre muhasebe kayıtları aşağıdaki gibi olacaktır:

\begin{tabular}{|c|c|c|c|}
\hline $\begin{array}{c}\text { Mad. } \\
\text { No }\end{array}$ & AÇIKLAMA & BORÇ & ALACAK \\
\hline & 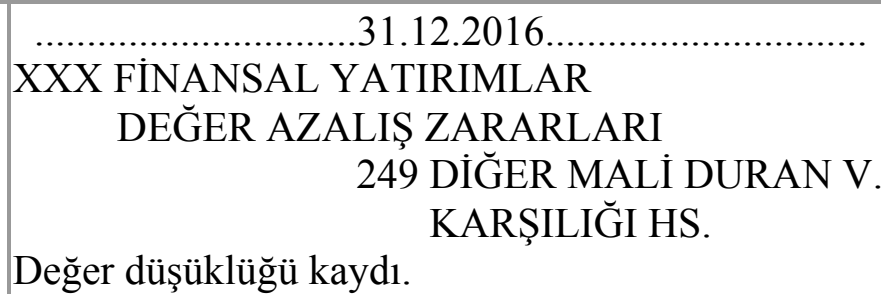 & 10.000 & 10.000 \\
\hline
\end{tabular}

\begin{tabular}{|c|c|c|c|}
\hline $\begin{array}{c}\text { Mad. } \\
\text { No }\end{array}$ & AÇIKLAMA & BORÇ & ALACAK \\
\hline & $\begin{array}{l}\text { 102 BANKALAR HESABI } \\
\text { 248 DİĞER MALİ DURAN } \\
\text { VARLIKLAR HESABI } \\
\text { XXX FINANSAL YATIRIMLAR } \\
\text { DEĞER ARTIŞ } \\
\text { Satıș kaydı. } \\
\text { KAZANÇLARI }\end{array}$ & 110.000 & $\begin{array}{l}100.000 \\
10.000\end{array}$ \\
\hline & $\begin{array}{l}\text { 249 DİGER MALİ DURAN V. } \\
\text { KARŞILIĞI HS. } \\
\text { YATIRIMLAR } \\
\\
\\
\text { XXX FINANSAL } \\
\text { KAZĞER ARTIŞ } \\
\text { KACCLARI }\end{array}$ & 10.000 & 10.000 \\
\hline
\end{tabular}

\section{Sonuç}

Bağımsız denetime tabi şirketler kapsamının yıllar itibari ile artması, bu şirketlerin finansal bilgi sunmak amacıyla hazırladıkları finansal raporlarının evrensel niteliğe ve bağımsız denetime uygun bir forma dönüştürülmesi ihtiyacını da arttırmıştır. Bu kapsamda hazırlanmış olan BOBİ FRS setinin 2018 yılından itibaren yürürlüğe girmesi ile birlikte söz konusu beklentilerin kısmen de olsa karşılanmaya başlanacağ düşünülmektedir. 
BOBİ FRS setinin yürürlüğe girmesi ile birlikte MSUGT'de yer almamakla birlikte, Avrupa Birliği direktiflerinde yer alan bazı muhasebe yaklaşımları da uygulanmaya başlanacaktır. Ancak yine de, BOBİ FRS'nin Avrupa Birliği direktifleri doğrultusunda şekillenen TFRS uygulamalarında önemli ölçüde farklılıklar içeriyor olması, BOBİ FRS'nin uluslararası ölçekte kabul edilebilir bir uygulama seti olmaktan ziyade, yalnızca bağımsız denetimin kabulü ve devamı için uygun bir raporlama seti oluşturduğu yönünde bazı eleştirileri de beraberinde getirmektedir.

TFRS'ye göre bir şirketin hazırlaması gereken finansal rapor seti finansal durum tablosu, kapsamlı gelir tablosu, nakit akış tablosu, özkaynak değişim tablosu ve dipnotlardan oluşmakta iken; BOBİ FRS'de TFRS'lerden farklı olarak kapsamlı gelir tablosu yerine yalnızca kar veya zarar tablosu düzenlenmesi gerektiği belirtilmektedir. Dolayısıyla, BOBİ FRS ile birlikte diğer kapsamlı gelir tablosunun olmadığı ve ilk muhasebeleştirmeden sonraki ölçümlerde yapılan sınıflandırma sonucunda ortaya çıkan farkların yalnızca kar veya zarar tablosuna alınabildiği bir metin yürürlüğe girmiştir.

BOBİ FRS'nin uygulanmaya başlanmasından sonra karşılaşılabilecek bir diğer problem ise mevcut muhasebe kayıt sisteminde kullanılan Tek Düzen Hesap Planı'nda yer alan hesapların yeni sette belirtilen bazı hesapları karşılama noktasında yetersiz kalmasıdır. Özellikle değer düşüklüğü ile ilgili muhasebeleştirmeler için bazı yeni hesapların tanımlanması gerekmektedir. Aksi takdirde, yeni sette önerilen hesap kalemleri yerine, BOBİ FRS'nin özünü tam olarak karşılayamayan ve mevcut kayıt sisteminde halihazırda kullanılan hesap kalemleri BOBİ FRS uygulayan işletmeler tarafinda da zorunlu olarak kullanılmaya devam edilecektir.

Finansal durum tablosunun önemli bir bölümünü oluşturan finansal varlıkların ilk muhasebeleştirmesinde; TFRS 9'a göre yapılan sınıflamada itfa edilmiş maliyeti ile ölçülen, gerçeğe uygun değer farkı kar veya zararda sınıflandırılarak ölçülen ve gerçeğe uygun değer farkı diğer kapsamlı gelirde sınıflandırılarak ölçülen finansal varlıklar olmak üzere üçlü bir sınıflama yapılmaktadır. BOBİ FRS'deki finansal varlık sınıflamasında ise ticari ve diğer alacaklar, borçlanma araçları, özkaynak araçlarındaki yatırımlar ve diğer finansal varlıklar yer almaktadır. BOBİ FRS'de yer alan bu sınıflama, TFRS 9'dan farklı olarak finansal varlıkla ilgili ölçülen gerçeğe uygun değer farkının diğer kapsamlı gelirde raporlanmasına olanak tanımamaktadır. Bununla birlikte, finansal varlıklardaki değer düşüklüğü için TFRS 9'da belirtilen beklenen kredi zararı yaklaşımı BOBİ FRS'de yer almamaktadır. Bu farklılıklar, BOBİ FRS'de yer alan finansal varlıklarla ilgili ilkelerin TFRS setinde biçim olarak benzemekle birlikte, öz olarak MSUGT'e daha uygun olduğu algısını yaratmaktadır.

\section{KAYNAKÇA}

Biçer, Seyra Özge (2016), “Türkiye Finansal Raporlama Standartları Uyarınca Finansal Araçların Ölçümü ve Muhasebeleştirilmesi”, Muhasebe ve Denetim Dünyası, Cilt: 1, Sayı: 3, s. $85-119$.

Burton, F. Greg (2012), "A Cross-Cultural Study of the Influence of Country of Origin, Justice, Power Distance, and Gender on Ethical Decision Making”, Journal of International Accounting Research, Cilt: 11, Say1: 1, s. 35 - 44.

Örten, Remzi - Kaval, Hasan - Karapınar, Aydın (2017), "Türkiye Muhasebe Finansal Raporlama Standartları Uygulama ve Yorumları”, 10. Bask1, Gazi Kitabevi, Ankara. 
Özerhan, Yıldız (2016), "Yerel Finansal Raporlama Çerçevesi Taslağındaki Ölçümleme Esasları Üzerine Bir Değerlendirme”, Muhasebe Bilim Dünyası Dergisi, Cilt: 18, Say1: 2, s. $307-336$.

TFRS 9 FINANSAL ARAÇLAR STANDARDI. www.kgk.gov.tr (Erişim Tarihi: 15.03.2017)

TFRS 15 MÜŞTERİ SÖZLEŞMELERINNDEN HASILAT STANDARDI. www.kgk.gov.tr (Erişim Tarihi: 15.03.2017)

TMS 32 FINANSAL ARAÇLAR: SUNUM STANDARDI. www.kgk.gov.tr (Erişim Tarihi: 15.03.2017)

TMS 39 FINANSAL ARAÇLAR: ÖLÇME VE MUHASEBELEŞTIRME STANDARDI. www.kgk.gov.tr (Erişim Tarihi: 15.03.2017)

Yünlü, Murat (2016), "Bağımsız Denetime Tabi Olup TMS/TFRS'leri Uygulama Kapsamında Olmayan İşletmeler İçin Finansal Raporlama Standartları", Muhasebe ve Denetim Dünyas1, Cilt: 1, Say1: 1, s. $23-42$. 


\title{
Comparison of the Measurement and Accounting Principles of Financial Assets in Terms of the Financial Reporting Standard for Large and Medium-Sized Enterprises and Turkish Financial Reporting Standards
}

\author{
Erkan ÖZTÜRK \\ Kırklareli University \\ Faculty of Economics and Administrative Sciences \\ Kirklareli, Turkey \\ orcid.org/0000-0002-9356-1557 \\ erkan.ozturk@klu.edu.tr
}

\section{Extensive Summary}

\section{Introduction}

International Financial Reporting Standards (IFRS) have been developed to provide comparable, reliable, understandable and transparent financial reports. Businesses that wish to exist in international financial markets regulate their financial reports according to IFRS, which is accepted as the common language of accounting. There are also many studies to aid to prepare comparable financial reporting at international level in Turkey. For this purpose, IFRS has been translated into Turkish under the title of Turkish Financial Reporting Standards (TFRS) and has been partially applied since 2005 .

In Turkey, companies that are classified as public interest entities (KAYİK) prepare their financial reports in accordance with TFRS. On the other hand, the number of companies that do not apply TFRS, but subject to independent audit has increased day by day. For this reason, the need for local financial reporting standards has increased over time. Based on this need, the notification on Financial Reporting Standard for Large and Medium-Sized Enterprises (BOBİ FRS) that was prepared by Public Oversight, Accounting and Auditing Standards Authority was published on 29/07/2017 and entered into force. Firms that are subject to independent audit and don't apply Turkish Financial Reporting Standards (TFRS) must prepare their financial statements according to this new set during fiscal periods starting on after 01/01/2018.

In this study, comparison of financial assets that have an important place in Turkish Financial Reporting Standards set has been made in terms of Turkish Financial Reporting Standards (TFRS) and Financial Reporting Standard for Large and MediumSized Companies (BOBİ FRS). At the end of the study, several examples have been presented to explain the detected differences.

\section{The Coverage of BOBİ FRS}

BOBİ FRS is an accounting standard list for the companies that do not apply TFRS to prepare their financial reports but wish to report at international level. According to Article 6 of BOBİ FRS that published in The Official Gazette dated $29 / 07 / 2017$, companies that exceed at least two of the following criteria in two accounting periods have to apply BOBİ FRS: 
- Total Assets, 75 Million and over Turkish Liras.

- Annual Net Sales Revenue, 150 Million and over Turkish Liras.

- Average Number of Employees, 250 and over.

\section{Convergence Characteristics of the BOBİ FRS Set to the TFRS with respect to Financial Assets}

Some of the convergence characteristics of the BOBİ FRS set to the TFRS related to the measurement of financial assets are as follows:

- Valuation in BOBİ FRS is arranged according to the valuation criteria in TFRS. However, despite the difficulties in practice, there have been some restrictions on the implementation of these criteria in BOBİ FRS.

- There are differences between TFRS and BOBİ FRS in terms of measurement of revenue. In case of a maturity that is less than 1 year, measurement is made with maturity value instead of cash value.

- In TFRS, the first recognition of trade and other receivables and trade and other payables are measured at transaction price. Subsequent measurements are measured at amortized cost. The differences calculated according to the effective interest method are recognized in profit or loss section. In BOBİ FRS, in case of a maturity that is more than 1 year, this measurement is performed as in TFRS.

\section{Comparison of the BOBİ FRS and the TFRS with respect to Financial Assets}

Classification of Financial Assets in BOBİ FRS:

- Trade and Other Receivables

- Debt Instruments

- Investments in Equity Instruments

- Other Financial Assets

Affiliates and subsidiaries are not classified as financial assets in BOBİ FRS.

Initial Recognition of Financial Assets in BOBİ FRS:

- $\quad$ Trade and Other Receivables with maturity not exceeding 1 year are measured at nominal value. On the other hand, trade and other receivables with a maturity more than 1 year are measured at amortized cost as in TFRS 9.

- $\quad$ The initial recognition of debt instruments in BOBİ FRS is measured at the transaction price. The costs incurred for the transaction are included in the transaction price.

Investments in equity instruments are measured different forms in BOBI FRS, depending on whether they are traded on the stock exchange and/or other organized markets. Equity instruments traded on the stock exchange and/or other organized markets are measured at transaction price at initial recognition and transaction costs are reflected in profit or loss. Equity instruments that are not traded on the stock exchange and/or other organized markets are measured at cost value, which is the sum of transaction costs and transaction costs at initial recognition. 
Subsequent Measurement of Financial Assets in BOBİ FRS:

- The maturity period for subsequent measurement of trade and other receivables is determinative in BOBI FRS. Trade and other receivables with a maturity not exceeding one year are measured at nominal value, with a maturity over one year are measured at amortized cost as in IFRS 9. In the case of impairment, the impairment loss is calculated. Impairment losses for trade and other receivables are reflected to "Other Expenses from Operating Activities" item on trade receivables.

- There is no classification in BOBİ FRS for borrowing instruments in terms of subsequent measurement as in TFRS 9. Nevertheless, it is stated in BOBİ FRS that borrowing instruments must be measured at amortized cost.

- According to BOBİ FRS, measurement of equity instruments has two different applications. Equity instruments traded on the stock exchange and / or other organized markets are measured at fair value at the reporting date and the resulting value differences are reflected in profit or loss in the "Appreciation Income in Financial Assets" or "Impairment Losses in Financial Investments". Equity instruments that are not traded on the stock exchange and / or other organized markets are measured at cost value with impairment loss.

\section{Conclusion and Discussions}

Some accounting approaches that are in the European Union directives but not in General Communique on Accounting System Application (MSUGT) will also begin to be implemented with the entry into force of the BOBİ FRS. In this manner, it will also be ensured that the financial reports of the companies are transformed into a universal form. 